obtainable death not a marathon of misery, a high-tech horror story.

This is an important text, worthy of study by both the medical team and the managers. Absorb the detail before concluding it couldn't happen here, for it so easily could. Managerial choice is rarely seen as involving an ethical decision, and if it is then unexamined utilitarian principles rule. It is ironic that Frost's words "take you in" can carry the scent of a con-trick - to be taken in - though con-tricks only work when the victim thinks he or she is getting a better than expected deal. Let us not be conned: high-tech home care, a streamlined parachute? This excellent text will serve its purpose if we stop and consider before mounting the rollercoaster of high-tech home care.

GORDON LENNOX

General practitioner

\section{Ethical Aspects of Human Reproduction}

Edited by Claude Sureau and Francoise Shenfield, Paris, John Libbey Eurotext Paris, 377 pages, $160 \mathrm{FF}$

This book of proceedings and papers was published following the FIGO symposium on ethics in reproductive medicine and biology held in Paris in 1994. As half the papers are written in English and half in French, it is not the easiest of books to delve into: papers are written primarily in one language and then summarised in the other. However, the careful editing and natural overlap between presenters allows for adequate coverage of all the major ethical problems encountered by clinicians in reproductive medicine.

Clearly divided into sessions, topics included are research on pre-embryos; the use of fetal tissue for transplantation; sex selection; surrogacy, and the practice of female genital mutilation. Debates and discussions between contributors following each paper raise interesting issues from different parts of the globe.

Malcolm Macnaughton's clear account of surrogacy and gamete donation in the UK is excellent, explaining the differences following the Surrogacy Act of 1985 and the HFEA Act of 1990, the latter clarifying the legal status of the child and donor. The papers on the use of fetal tissue for transplantation attempt to explore the ethical minefield surrounding this area. The question of "when does life begin" is explored, and hence when fetal tissue can be obtained. One author suggests that since the fetus cannot perceive pain until 20-22 weeks, then it would seem reasonable to retrieve tissue only before this gestation. A set of guidelines are offered that should ensure that the decision to abort is kept separate from the decision to use fetal tissue. The section on female genital mutilation is interesting, pointing out that this affects 100 million women worldwide. While there appears to be clear consensus that mutilating operations on unconsenting children are abhorrent, the question of whether re-infibulation following childbirth is unethical is rather different. Although the Royal College of Obstetrics and Gynaecology has favoured a ban on re-infibulation, one author feels that this operation on a consenting adult is an entirely different issue and that it is possible to favour such an operation without necessarily condoning the practice of genital mutilation in the first place.

This concise book is of value to all of us working in the field of reproductive medicine, where ethical dilemmas are faced regularly, as well as those interested in medical ethics. It does not attempt to provide answers but succeeds in stimulating discussion and, as such, is a useful addition to any bookshelf.

LESLEY REGAN
Department of Obstetrics and
Gynaecology, Imperial College School of
Medicine at St Mary's, Norfolk Place,
London W2 $1 P G$

\section{Books: information and orders}

If you wish to order or require further information regarding the titles reviewed here, please write to or telephone the BMJ Bookshop, PO Box 295, London WC1H 9JR. TelO 0171383 6244. Fax: 01713836662 Books are supplied post free in the UK and for BFPO addresses: Overseas customers should add 15 per cent for postage and packing. Payment can be made by cheque in sterling drawn on a UK bank or by credit card (Mastercard, Visa, or American Express, stating card number, expiry date, and full name (The price and availability are occasionally subject to revision by the publishers). 